\title{
Implications for the use of sedimentary invertebrate communities to infer past presence of fish
}

\author{
L. Nevalainen ${ }^{(1)}$, T.P. Luoto(1) \\ Received March 31, 2010 / Reçu le 31 mars 2010 \\ Revised May 5, 2010 / Révisé le 5 mai 2010 \\ Accepted May 10, 2010 / Accepté le 10 mai 2010
}

Key-words: Chaoborus, Chironomidae, Cladocera, community structure, paleolimnology, predation

\section{ABSTRACT}

We investigated surface sediment assemblages of invertebrates from nine shallow lakes in southern Finland and assessed the relationship between invertebrate assemblages and fish status at local scale for the purpose of paleolimnological food-web studies. Invertebrate-based cluster analysis separated the fish-free lakes into their own group and the results also showed a strong and statistically significant relationship between fish status and faunal sedimentary assemblages. The present results from the local data set indicate good potential for developing quantitative invertebrate-based paleolimnological fish status models in the future. However, for the implementation of the models substantially more lakes with different fish status need to be examined that the effect of fish predation on invertebrate communities can be separated from other limnological forcing mechanisms.

\section{RÉSUMÉ}

Implications sur l'usage des communautés d'invertébrés sédimentaires pour inférer la présence passée de poisson

\begin{abstract}
Mots-clés :
Nous avons étudié les communautés d'invertébrés du sédiment de surface de Chaoborus, Chironomidae, Cladocera, structure de communauté, paléolimnologie, prédation neuf lacs peu profonds du sud de la Finlande et établi la relation entre les assemblages d'invertébrés et le statut piscicole à l'échelle locale dans le but d'études paléolimnologiques des réseaux trophiques. L'analyse de classification basée sur les invertébrés a séparé les lacs sans poissons en un groupe isolé et les résultats ont aussi montré une forte et statistiquement significative relation entre le statut piscicole et les assemblages de faune sédimentée. Ces résultats d'un jeu de données locales indiquent un bon potentiel futur pour le développement de modèles quantitatifs du statut piscicole ancien basés sur la paléolimnologie des invertébrés. Toutefois, l'implémentation des modèles demande bien plus de lacs étudiés de différents statuts piscicoles de façon à ce que l'effet de la prédation sur les communautés d'invertébrés puisse être séparé des autres mécanismes limnologiques de forçage.
\end{abstract}

(1) Department of Geosciences and Geography, P.O. Box 64, University of Helsinki, FIN-00014, Finland, liisa.nevalainen@helsinki.fi 


\section{INTRODUCTION}

Freshwater lakes are currently highly stressed by human influence, for example pollution, draining and biomanipulation (Brönmark and Hansson, 2002). The human impact has intensified in modern times but in many cases it has prevailed for many decades or even centuries. Therefore, changes in various external factors, such as in temperature and nutrients influencing limnological and ecological status of lakes have gained much attention among paleolimnologists (e.g. Lotter et al., 1997, 1998; Jeppesen et al., 2001a; Smol et al., 2005; Smol and Douglas, 2007). Reconstructions of past internal changes in lakes and their food-web structures have been performed using fossil remains of aquatic organisms in lake sediments, mostly remains of phytoplankton (diatoms and chrysophytes), zooplankton and zoobenthos (Cladocera, Chironomidae, Chaoboridae) (e.g. Sarmaja-Korjonen, 2002; Salonen et al., 2006; Luoto et al., 2008). Since fish body parts do not commonly preserve as fossils in lake sediment (Patterson and Smith, 2001) their past presence have been be tracked indirectly via fossil assemblages of their prey organisms that preserve in the sediments (e.g. Kitchell and Kitchell, 1980; Nykänen et al., 2006; Manca et al., 2007).

The ecological role of fish in lake ecosystems is invaluable, because they affect the abundance and diversity of their prey organisms, such as planktonic and benthic Cladocera and Diptera larvae (Kornijóv et al., 2005; Vašek et al., 2006; Davidson et al., 2007) through topdown control (Vanni et al., 1997). Fish are also significant due to their participation in internal loading and recycling of nutrients that may affect planktonic organisms (Horppila et al., 1998). The major structuring effect of fish predation on their prey is due to size-selectivity that leads to the dominance of small species and removal of large ones, thus changing community structures (Brooks and Dodson, 1965). However, fish do not necessarily always prey on largest species, but the most visible (e.g. highly pigmented) ones. This visibility selection of fish may also cause changes in their prey communities (Zaret, 1972; Zaret and Kerfoot, 1975). For studies on past fish stocks, Jeppesen et al. (1996) created the first quantitative paleolimnological reconstruction model using the relationship between cladoceran remains and planktivorous fish. Prior to this quantitative method, cladoceran assemblages and morphology had been used in many studies to identify past changes in fish stocks and predation (Kerfoot, 1974, 1981; Salo et al., 1989). More recently, Jeppesen et al. (2002, 2003) showed that size and abundance of ephippia of some planktonic cladoceran species are related to fish abundance and can therefore be used as indicators for planktivorous fish stocks. Also, the well-preserved mandibles of Chaoborus (Chaoboridae) larvae have been used to infer changes in past fish populations, since Chaoborus occurs in fish-free lakes or in lakes with refugia (hypolimnion) against fish predation (Uutala, 1990; Sweetman and Smol, 2006; Luoto and Nevalainen, 2009).

As stated above, in previous studies fish presence has been inferred using a single group of organisms, mostly Cladocera or Chaoborus. However, Sweetman and Smol (2006) suggested that the use of multiple proxies, i.e. several faunal groups together, may improve the past fish inferences. Therefore, in order to test the relationship between local invertebrate communities and fish status, we investigated fossil invertebrate assemblages from surface sediments of nine shallow and limnologically diverse lakes with different fish status in southern Finland. We included and enumerated all identifiable fossil invertebrate taxa (Cladocera, Diptera, Ephemeroptera, Trichoptera, and Oribatida) in the surface sediment samples and analyzed statistically their incidence in relations to different environmental variables. Our main aim was to distinguish the local relationship between invertebrate taxa and fish status and to assess the potentialities of fossil invertebrate assemblages as indicators for presence or absence of fish in future paleolimnological studies. 

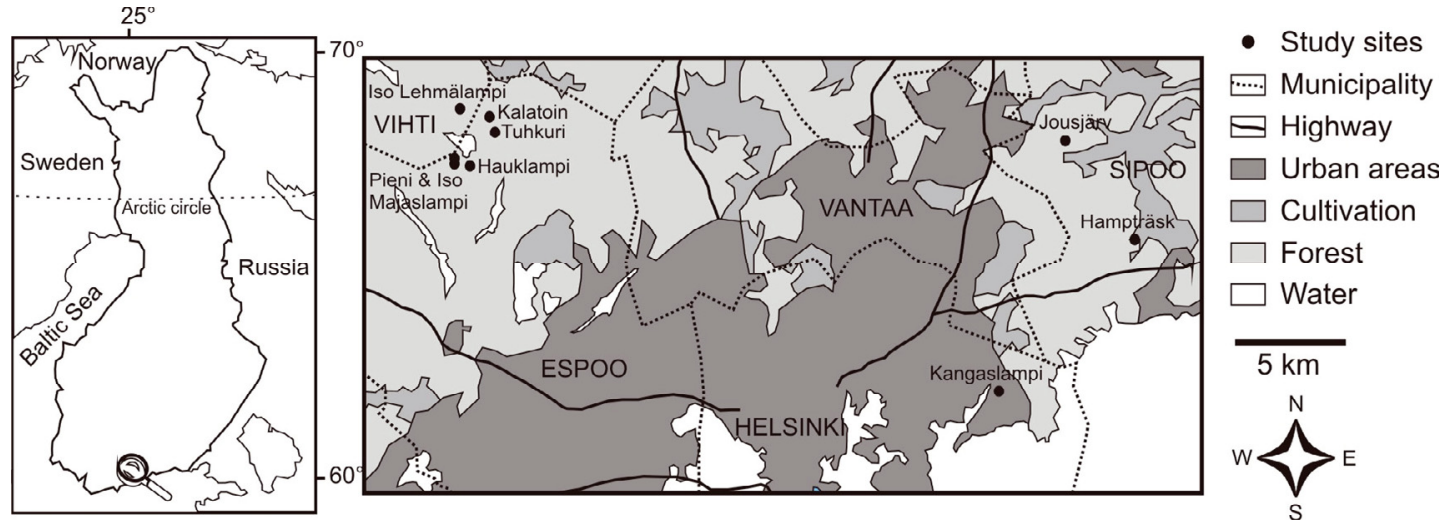

\section{Figure 1}

Distribution of the nine study lakes in southern Finland.

Figure 1

Situation des neufs lacs étudiés au sud de la Finlande.

\section{Table I}

Measured limnological variables (summer 2005) and fish status for the nine study lakes.

Tableau I

Variables limnologiques mesurées (été 2005) et statut piscicole des neuf lacs étudiés.

\begin{tabular}{|c|c|c|c|c|c|c|c|c|}
\hline & $\begin{array}{l}\text { Depth } \\
(\mathrm{m})\end{array}$ & $\mathrm{pH}$ & $\begin{array}{c}\text { Conductivity } \\
\left(\mu \mathrm{s} \cdot \mathrm{cm}^{-1}\right)\end{array}$ & $\begin{array}{c}\mathrm{DO} \\
\left(\mathrm{mg} \cdot \mathrm{L}^{-1}\right)\end{array}$ & $\begin{array}{c}\text { Color } \\
\left(\text { Pt.mg. L- }{ }^{-1}\right)\end{array}$ & $\begin{array}{c}\mathrm{TP} \\
\left(\mu \mathrm{g} \cdot \mathrm{L}^{-1}\right)\end{array}$ & $\begin{array}{c}\text { TN } \\
\left(\mu g \cdot L^{-1}\right)\end{array}$ & Fish \\
\hline 1. Kalatoin (KAL) & 5.9 & 4.5 & 26 & 8.9 & 100 & 24 & 526 & No \\
\hline 2. Hauklampi (HAU) & 4.4 & 5.0 & 19 & 10.5 & 25 & $<10$ & 140 & Yes \\
\hline 3. Iso Majaslampi (IML) & 4.1 & 4.8 & 19 & 9.6 & 30 & $<10$ & 201 & Yes \\
\hline 4. Pieni Majaslampi (PML) & 4.2 & 4.9 & 16 & 9.7 & 25 & $<10$ & 191 & Yes \\
\hline 5. Iso Lehmälampi (ILL) & 4.1 & 5.1 & 17 & 8.9 & 30 & 25 & 382 & Yes \\
\hline 6. Tuhkuri (TUH) & 1.5 & 5.6 & 25 & 10.4 & 50 & 31 & 768 & Yes \\
\hline 7. Jousjärv (JOU) & 5.4 & 6.2 & 34 & 7.6 & 125 & 25 & 624 & No \\
\hline 8. Hampträsk (HAM) & 2.4 & 6.6 & 49 & 9.2 & 75 & 58 & 1123 & Yes \\
\hline 9. Kangaslampi (KAN) & 1.6 & 7.2 & 157 & 9.0 & 37.5 & 76 & 813 & No \\
\hline
\end{tabular}

\section{MATERIAL AND METHODS}

\section{$>$ SITES}

The nine study lakes are distributed in close proximity to each other in southern Finland, near the Helsinki district (Figure 1). They are all enclosed basins without any major inlets or outlets. The limnological variables: $\mathrm{pH}$, conductivity, dissolved oxygen (DO), color, total phospohorous (TP) and total nitrogen (TN) of the lakes were highly variable ranging from acidic to circum neutral, from clear to brown-water, and from oligo- to eutrophic (Table I). The fish status of the lakes also varied, six of the lakes are currently inhabited by fish and three lakes are without permanent fish populations (Table I).

Lake Kalatoin is a fish-free, very acidic and dystrophic small (about 1 ha) lake. Sphagnum mosses and Carex spp. dominate the shores and the submerged vegetation consists of aquatic mosses and Nuphar lutea. The lake is surrounded by a small catchment with bog vegetation and several bedrock outcrops. Lakes Hauklampi (area 2.7 ha), Iso Majaslampi (area $6.3 \mathrm{ha}$ ), and Pieni Majaslampi (area about $1 \mathrm{ha}$ ) are located close to each other. They are acidic and oligotrophic lakes, with small and nutrient-poor catchments. Patches of mire, fractured bedrock outcrops, and Pinus forests cover the catchments, shores are inhabited by Carex spp. and Sphagnum mosses, and the aquatic macrophyte zone consists only of Nymphaea alba. Due to acidification (Kauppi et al., 1990) the natural fish populations, consisting mainly 
of European perch (Perca fluviatilis), died out in the lakes in the 1980s. The lakes experienced a chemical recovery process during the 1990s. In 2002, perch were introduced into these lakes (35-120 per hectare), aiming to re-establish the populations (Nyberg et al., 2010). Lake Iso Lehmälampi (area about $3 \mathrm{ha}$ ) is also an acidic and oligotrophic upland lake. The catchment is characterized by the presence of bedrock outcrops and paludified areas. The lake also experienced severe acidification in the 1980 s and the succeeding recovery process in the 1990s. The lake became almost fish-free during the acidification (Verta et al., 1990), but has since exhibited several introductions of whitefish (Coregonus lavaretus), roach (Rutilus rutilus), and perch (Nyberg et al., 2010). Sphagnum mosses, Carex spp., and submerged Nuphar lutea and Nymphaea alba dominate the littoral and the shoreline. The rocky and paludified catchment is rather small and poor in nutrients. Lake Tuhkuri is an oligotrophic forest lake with surface area of 13.7 ha and it maintains a successful fish stock consisting mainly of perch. Several houses and summer houses are situated on its shores and the catchment is characterized by mixed forest (Picea, Pinus, Betula) and some bedrock outcrops. The aquatic vegetation consists of Phragmites australis, Nuphar lutea, and aquatic mosses. Jousjärv is a fish-free small (about 0.5 ha), dystrophic lake with paludified shores; Sphagnum mosses and Carex spp. cover the entire shoreline. Small hills with bedrock outcrops characterize the catchment. The paludified area surrounding the lake is ditched. Lake Hampträsk (area about $4 \mathrm{ha}$ ) is a shallow and meso-eutrophic with human influence on its surroundings and fish, mostly perch, inhabiting the basin. There are fields and houses near the lake and the paludified western shore is ditched. The aquatic vegetation consists mainly of Phragmites australis and Nuphar lutea. Lake Kangaslampi is a fish-free shallow, small (about 1 ha), eutrophic, and disturbed lake of natural origin with very high human impact. The lake is located in a suburb of Helsinki near the Baltic Sea within a densely inhabited area. The catchment is mostly built up, except for a small park. During the summer, algal blooms dominate the aquatic environment and thus oxygen depletion during the winter and summer is inevitable.

\section{> SAMPLING AND SAMPLE ANALYSES}

Surface sediments (topmost 1-2 cm) from the nine study lakes were sampled with a Limnos gravity corer through ice in February and March 2005. Limnological measurements were taken from the epilimnion during summer in 2005 with an Orion Model $1230 \mathrm{pH} / \mathrm{mV} / \mathrm{ORP} / \mathrm{conductivity/dissolved} \mathrm{oxygen/salinity/temperature} \mathrm{meter} \mathrm{(Thermo} \mathrm{Fisher}$ Scientific, Waltham, MA, USA). In the laboratory the sediment samples were prepared for fossil Cladocera analyses according to methods described in Szeroczyńska and SarmajaKorjonen (2007) and for fossil chironomid and zoological macroremain analysis according to methods described in Brooks et al. (2007) and Luoto (2009). For Cladocera analysis the sediment samples were heated and stirred in $10 \% \mathrm{KOH}$ on a hot plate for approximately 20 minutes. After the heating, samples were sieved through a $44-\mu \mathrm{m}$ mesh and mounted in glycerine jelly on preparation slides. A minimum of 200 carapaces of the Chydoridae and all the other identifiable cladoceran remains were identified and counted under a light microscope and the most abundant body part was chosen for each species to represent its individuals. The proportional abundances for all cladoceran species were calculated from the sum of total individuals. For zoological macroremain analysis (i.e. Diptera, Ephemeroptera, Trichoptera, Oribatida) the sediment samples were treated with warm $10 \% \mathrm{KOH}$ for $10-20$ minutes and sieved through a $100-\mu \mathrm{m}$ mesh. The residue was examined under a stereomicroscope and remains were handpicked with fine forceps for exact identification and enumeration. The remains were mounted on Euparal, the identification was performed under a light microscope and a minimum of 100 chironomid headcapsules and other identifiable zoological macroremains were counted. The proportional abundances of all invertebrates were calculated from the total number of counted individuals so that the Cladocera and Diptera were considered separately in the abundance calculation, but proportions of other invertebrate groups (Ephemeroptera, Trichoptera, Oribatida) were calculated from the total sum of Diptera and other invertebrates. The proportional abundances of these separate faunal groups were used in the statistical analyses. 


\section{> DATA ANALYSES}

Two-way indicator species analysis (TWINSPAN) was used as a divisive technique to classify the nine lakes according to their invertebrate assemblages with pseudospecies cut levels set to $0,2,5,10$ and $20 \%$. Relative species abundances were used with square-root transformation of species data and downweighting of rare species to stabilize the variance. The TWINSPAN was performed using the program WinTWINS, version 2.3 (Hill and Šmilauer, 2005).

Detrended correspondence analysis (DCA) was applied to choose between linear- or unimodal-based methods in further numerical analyses by estimating the lengths of compositional gradients (DCA axes 1 and 2). The DCA was run with detrending by segments and using square-root transformation of species data and downweighting of rare species. No transformations were performed for environmental data. Of the environmental variables, fish presence was entered as nominal variables, using binary codes (value 0 when absent and 1 when present). DCA is an indirect ordination method that summarizes the variation in species assemblages along the DCA axes (ter Braak, 2003). Redundancy analysis (RDA) was chosen (lengths of DCA gradients $<2$ ) to explore relationships between invertebrate assemblages and environmental variables. RDA is a linear technique that can be used to identify environmental variables that are strongly related to the species assemblages. The RDAs were performed using correlation matrix, square-root transformation of species data, and downweighting of rare species and run with only one environmental variable at a time to test the statistical significance of the variables. The significance of each variable was tested with a Monte Carlo permutation test (999 unrestricted permutations) and variables were considered significant if the permutation test value was $P \leq 0.05$. When only one environmental variable is used, the ratio of the first constrained eigenvalue $\left(\lambda_{1}\right)$ to the second unconstrained eigenvalue $\left(\lambda_{2}\right)$ indicates the relative significance of the specific variable in explaining the cumulative variance in the species data. Explanatory variables that have high $\lambda_{1}: \lambda_{2}$ ratios can be used in quantitative inference models. For RDA ordination the analysis was run with the most significant environmental variables (fish, DO, color, TP). The DCAs and RDAs were performed using the program CANOCO, version 4.52 (ter Braak, 2003).

\section{RESULTS}

A total of 98 taxa, mostly Cladocera (39) and Chironomidae (54), were identified from the surface sediment samples of the nine lakes (Table II). Taxa occurring in all the lakes included Bosmina (Eubosmina) (Bosminidae), Alona affinis, Alona guttata var. tuberculata, Alonella excisa, Alonella nana, and Chydorus sphaericus s.I. (Chydoridae) of the Cladocera and Ablabesmyia monilis-type, Procladius, Psectrocladius (Allopsectrocladius), and Psectrocladius sordidellus-type of the Chironomidae. Other widely occurring taxa (in eight lakes) were cladoceran Acroperus harpae and chironomids Chironomus anthracinustype and Dicrotendipes pulsus-type. In addition to Cladocera and Chironomidae, dipteran taxa Chaoborus flavicans (in four lakes) and Bezzia-type (Ceratopogonidae) (in seven lakes) were found in the samples (Table II). The remains of Ephemeroptera (in five lakes), Oribatida (in five lakes) and Trichoptera (in Hampträsk) were also found (Table II).

The TWINSPAN classified the lakes according to their fauna into two separate groups; lakes with fish (Hampträsk, Tuhkuri, Hauklampi, Iso Majaslampi, Pieni Majaslampi, and Iso Lehmälampi) and those without fish (Kalatoin, Jousjärvi, Kangaslampi) (Figure 2). The analysis also pointed the indicator taxa of particular lake groups or lakes. Indicator species for fish-free lakes were cladocerans Alona guttata var. tuberculata, Alonella excisa, Alonella nana, Chydorus sphaericus s.I., and chironomids Psectrocladius sordidellus-type, Psectrocladius (Allopsectrocladius), and Corynoneura lobata-type. Chaoborid Chaoborus flavicans, Ephemeroptera, and Oribatida were also included as indicative taxa of fish-free lakes.

The DCA axes showed gradient lengths $<2\left(\lambda_{1}=1.693, \lambda_{2}=1.204\right)$ and therefore the RDA was chosen to study the species-environment linkages. The limnological variables included 
Table II

Relative abundance of the invertebrate taxa in the surface sediments of the nine lakes. The abbreviations of the lakes are described in Table I. The codes for the individual taxa are used in Figures 2 and 3.

Tableau II

Abondance relative des taxons d'invertébrés dans les sédiments de surface des neuf lacs. Les abréviations des lacs sont dans le tableau I. Le code de chaque taxon est utilisé dans les figures 2 et 3 .

\begin{tabular}{|c|c|c|c|c|c|c|c|c|c|c|}
\hline \multirow[b]{2}{*}{ CLADOCERA } & Code & CAL & $\mathrm{AUU}$ & IML & PML & ILL & $\mathrm{UH}$ & $\mathrm{JOU}$ & HAM & CAN \\
\hline & & & & & & & & & & \\
\hline Leptodora kindti & Lepto kin & 0.0 & 0.0 & 0.0 & 0.0 & 0.0 & 0.0 & 0.0 & 0.9 & 0.0 \\
\hline Sida crystallina & Sida cry & 0.3 & 0.0 & 0.3 & 0.0 & 0.0 & 2.2 & 0.7 & 0.0 & 0.0 \\
\hline Diaphanosoma brachyurum & Diap bra & 0.3 & 0.0 & 0.0 & 0.3 & 0.0 & 0.0 & 1.1 & 0.0 & 0.0 \\
\hline Holopedium gibberum & Holo gib & 0.3 & 0.0 & 0.0 & 0.0 & 0.0 & 0.0 & 1.1 & 0.0 & 0.0 \\
\hline Daphn & Daphind & 0.0 & 0.0 & 0.0 & 0.0 & 0.0 & 0.0 & 5.7 & 0.0 & 0.0 \\
\hline Cariodaphnia spp. & Ceriind & 1.6 & 0.3 & 0.0 & 1.3 & 0.2 & 0.3 & 0.4 & 0.0 & 0.4 \\
\hline Simocephalus spp. & Simoind & 0.0 & 0.0 & 0.0 & 0.0 & 0.0 & 0.0 & 0.4 & 0.0 & 0.0 \\
\hline Bosmina (Eubosmina) & Bosmeub & 23.5 & 29.7 & 24.1 & 26.3 & 49.0 & 61.1 & 9.5 & 50.4 & 12.3 \\
\hline Bosmina longirostris & Bosm lon & 0.0 & 0.0 & 0.0 & 0.0 & 0.0 & 2.0 & 0.0 & 0.0 & 0.0 \\
\hline Ophryoxus gracilis & Ophr gra & 0.0 & 0.3 & 0.3 & 0.0 & 0.5 & 1.1 & 0.0 & 0.0 & 0.0 \\
\hline Streblocerus serricaudatus & Stre ser & 0.0 & 0.0 & 0.0 & 0.0 & 0.0 & 0.3 & 0.0 & 0.0 & 0.0 \\
\hline otrix dentata & Drep den & 0.0 & 0.0 & 0.0 & 0.0 & 0.0 & 0.5 & 0.0 & 0.0 & 0.0 \\
\hline leberis c & cur & 0.0 & 0.0 & 0.0 & 0.3 & 0.0 & 0.0 & 0.0 & 0.0 & 0.0 \\
\hline us lame & lam & 0.0 & 0.0 & 1.0 & 0.3 & 0.5 & 0.6 & 0.7 & 0.0 & 0.0 \\
\hline Cam & rec & 0.6 & 0.3 & 0.0 & 2.3 & 0.7 & 0.8 & 0.7 & 0.7 & 0.0 \\
\hline harpae & har & 11.4 & 4.8 & 9.9 & 15.8 & 10.0 & 4.5 & 7.8 & 2.6 & 0.0 \\
\hline elongata & Alon elo & 0.0 & 0.3 & 0.7 & 3.3 & 0.5 & 0.0 & 0.0 & 0.0 & 0.0 \\
\hline Alon: & Alon aff & 1.0 & 6.5 & 8.5 & 13.2 & 6.5 & 10.1 & 0.7 & 1.5 & 0.4 \\
\hline Alon & gua & 0.0 & 0.0 & 1.0 & 0.0 & 0.2 & 0.3 & 0.0 & 1.1 & 0.0 \\
\hline Alon & Alo & 1.6 & 0.3 & 0.7 & 0.3 & 0.0 & 0.8 & 0.0 & 0.2 & 0.4 \\
\hline tata va & Alon tub & 1.6 & 2.6 & 3.4 & 1.3 & 2.1 & 0.8 & 5.3 & 0.4 & 7.4 \\
\hline angula & Alon rec & 0.0 & 0.0 & 0.0 & 0.0 & 0.0 & 0.0 & 0.0 & .4 & 3.7 \\
\hline Alon & & 2.2 & 14.8 & 7.8 & 5.3 & 3.0 & 0.5 & 0.0 & 0.0 & 0.0 \\
\hline nedia & Alon int & 0.0 & 0.0 & 0.7 & 0.0 & 0.5 & 0.2 & 1.1 & 1.1 & 0.0 \\
\hline Gra & tes & 1.0 & 0.0 & 0.0 & 0.0 & 0.0 & 0.6 & 1.1 & 1.1 & 4.9 \\
\hline Alon & exc & 21.9 & 35.5 & 11.9 & 14.5 & 2.8 & 0.9 & 13.8 & 1.7 & 8.2 \\
\hline Alor & Alo & 21.3 & 3.2 & 25.9 & 11.5 & 20.0 & 9.0 & 24.7 & 18.6 & 17.3 \\
\hline Alor & Alo & 1.6 & 0.0 & 0.0 & 0.0 & 0.0 & 0.0 & 1.1 & 0.7 & 0.0 \\
\hline Disp & & 0.0 & 0.0 & 0.0 & 0.0 & 0.0 & 0.0 & 0.0 & 1.1 & 0.0 \\
\hline trunca & tru & 0.3 & 0.0 & 0.0 & 0.0 & 0.0 & 0.3 & 0.7 & 0.0 & 0.0 \\
\hline Peut & lae & 0.3 & 0.0 & 0.0 & 0.0 & 0.0 & 0.0 & 0.4 & 0.0 & 0.0 \\
\hline Pleu & & 0.0 & 0.0 & 0.0 & 0.0 & 0.0 & 0.0 & 0.0 & 0.2 & 0.0 \\
\hline sphaeı & sph & 7.0 & 1.3 & 2.0 & 3.0 & 1.4 & 2.3 & 17.0 & 17.2 & 44.9 \\
\hline Chyd & pig & 0.0 & 0.0 & 0.3 & 1.0 & 2.1 & 0.6 & 0.0 & 0.0 & 0.0 \\
\hline Chyc & & 0.0 & 0.0 & 0.3 & 0.0 & 0.0 & 0.0 & 0.0 & 0.0 & 0.0 \\
\hline Rhy & $\mathrm{fal}$ & 0.0 & 0.0 & 0.7 & 0.0 & 0.2 & 0.3 & 0.0 & 0.0 & 0.0 \\
\hline Una & lat & 1.0 & 0.0 & 0.3 & 0.0 & 0.0 & 0.0 & 0.4 & 0.0 & 0.0 \\
\hline Kurzi & & 0.3 & 0.0 & 0.0 & 0.0 & 0.0 & 0.0 & 0.0 & 0.0 & 0.0 \\
\hline $\begin{array}{l}\text { Polyphemus pediculus } \\
\text { CHIRONOMIDAE }\end{array}$ & Poly ped & 1.0 & 0.0 & 0.0 & 0.0 & 0.0 & 0.0 & 5.7 & 0.0 & 0.0 \\
\hline 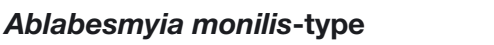 & 1on & 9.6 & 9.2 & 6.6 & 11.6 & 15.6 & 8.1 & 11.9 & 0.7 & 6.9 \\
\hline Procl & sind & 3.8 & 12.3 & 0.7 & 5.4 & 8.5 & 9.7 & 4.0 & 3.6 & 1.7 \\
\hline Cory & & 1.0 & 0.0 & 0.0 & 0.0 & 0.0 & 0.0 & 29.7 & 0.7 & 4.3 \\
\hline ura scu & Cory scu & 5.8 & 0.0 & 0.7 & 0.0 & 0.0 & 0.0 & 0.0 & 0.0 & 2.6 \\
\hline Cricot & Cric bic & 0.0 & 0.0 & 0.0 & 0.0 & 0.0 & 0.0 & 0.0 & 3.6 & 0.0 \\
\hline s (Isocla & & 0.0 & 0.0 & 0.7 & 0.0 & 0.0 & 0.0 & 0.0 & 0.0 & 0.0 \\
\hline Is undif. & Cricind & 1.9 & 0.0 & 0.0 & 0.0 & 0.0 & 0.0 & 1.0 & 2.2 & 3.4 \\
\hline Cricotopus undif. & Cric int & 1.9 & 0.8 & 0.7 & 0.0 & 0.7 & 2.4 & 0.0 & 2.2 & 1.7 \\
\hline Heterotrissocladius marcidus-type & Hete mar & 0.0 & 2.3 & 2.9 & 0.0 & 0.0 & 2.4 & 0.0 & 0.0 & 0.0 \\
\hline Heterotanytarsus apicalis-type & Hett api & 0.0 & 1.5 & 7.4 & 0.8 & 9.9 & 0.8 & 0.0 & 0.0 & 0.0 \\
\hline Limno & Limnind & 8.7 & 0.0 & 0.0 & 0.0 & 0.0 & 0.0 & 4.0 & 0.0 & 7.8 \\
\hline
\end{tabular}


Table II

Continued.

Tableau II

Suite.

\begin{tabular}{|c|c|c|c|c|c|c|c|c|c|c|}
\hline & Code & KAL & $\mathrm{HAU}$ & $\mathrm{IML}$ & PML & ILL & TUH & $\mathrm{JOU}$ & HAM & KAN \\
\hline Nanocladius rectinervis-type & Nano rec & 2.9 & 0.0 & 0.0 & 0.0 & 0.7 & 0.0 & 3.0 & 0.0 & 0.9 \\
\hline Mesocricotopus thienemannii & Mesc thi & 0.0 & 0.0 & 0.0 & 0.0 & 0.0 & 0.0 & 0.0 & 1.5 & 0.0 \\
\hline Orthocladius sp. & Orthind1 & 0.0 & 0.0 & 0.0 & 0.0 & 0.0 & 0.0 & 4.0 & 3.6 & 1.7 \\
\hline Psectrocladius (Allopsectrocladius) & Psecall & 25.0 & 0.8 & 2.2 & 4.7 & 0.7 & 2.4 & 15.8 & 3.6 & 0.9 \\
\hline Psectrocladius septentrionalis-type & Psec sep & 0.0 & 4.6 & 14.7 & 10.9 & 11.3 & 0.8 & 1.0 & 0.0 & 0.0 \\
\hline Psectrocladius sordidellus-type & Psec sor & 26.0 & 6.2 & 7.4 & 14.7 & 5.7 & 4.0 & 14.9 & 1.5 & 6.0 \\
\hline Psectrocladius barbatipes-type & Psec bar & 0.0 & 0.0 & 0.0 & 0.0 & 0.0 & 0.0 & 1.0 & 0.0 & 2.6 \\
\hline Micropsectra pallidula-type & Micr pal & 0.0 & 0.0 & 0.0 & 0.8 & 0.0 & 0.8 & 0.0 & 0.7 & 0.0 \\
\hline Constempellina brevicosta & Cons bre & 0.0 & 0.0 & 0.0 & 0.0 & 0.7 & 0.0 & 0.0 & 0.0 & 0.0 \\
\hline Paratanytarsus penicillatus-type & Part pen & 0.0 & 0.0 & 1.5 & 0.0 & 0.0 & 0.0 & 0.0 & 0.0 & 2.6 \\
\hline Paratanytarsus undif. & Partind & 0.0 & 6.2 & 2.2 & 0.8 & 0.0 & 1.6 & 0.0 & 2.2 & 1.7 \\
\hline Paracladopelma & Pardind & 0.0 & 0.0 & 0.0 & 0.0 & 0.0 & 0.0 & 0.0 & 0.7 & 0.0 \\
\hline Paratanytarsus austriacus-type & Part aus & 0.0 & 0.0 & 0.7 & 0.0 & 0.0 & 0.0 & 0.0 & 0.0 & 0.0 \\
\hline Zalutschia zalutschicola & Zalu zal & 0.0 & 2.3 & 0.0 & 3.1 & 3.5 & 5.6 & 0.0 & 5.1 & 0.0 \\
\hline Chironomus anthracinus-type & Chir ant & 3.8 & 9.2 & 5.1 & 5.4 & 8.5 & 0.8 & 0.0 & 13.1 & 0.9 \\
\hline Chironomus plumosus-type & Chir plu & 1.0 & 0.8 & 0.7 & 3.9 & 0.7 & 0.0 & 0.0 & 4.4 & 8.6 \\
\hline Cladopelma lateralis-type & Clad lat & 0.0 & 1.5 & 2.9 & 2.3 & 0.7 & 1.6 & 0.0 & 2.9 & 0.0 \\
\hline Dicrotendipes pulsus-type & Dicr pul & 0.0 & 6.2 & 4.4 & 3.9 & 6.4 & 12.1 & 1.0 & 4.4 & 5.2 \\
\hline Einfeldia $p$ & Einf pag & 0.0 & 0.0 & 0.0 & 0.0 & 0.0 & 0.0 & 0.0 & 6.6 & 1.7 \\
\hline Endochironomus albipennis-type & Endo alb & 0.0 & 0.8 & 0.0 & 0.0 & 0.0 & 0.0 & 0.0 & 2.2 & 0.0 \\
\hline Endochironomus tendens-type & Endo ten & 0.0 & 0.0 & 0.0 & 0.0 & 0.0 & 0.0 & 0.0 & 0.0 & 0.9 \\
\hline Endochironomus impar-type & Endo imp & 0.0 & 0.0 & 0.0 & 0.0 & 0.0 & 0.0 & 1.0 & 0.0 & 0.0 \\
\hline Glyptotendipes pallens-type & Glyp pal & 0.0 & 0.0 & 0.0 & 0.0 & 0.0 & 0.0 & 0.0 & 1.5 & 10.3 \\
\hline Lauterborniella agrayloides-type & Laut agr & 1.0 & 0.0 & 1.5 & 2.3 & 0.0 & 0.0 & 0.0 & 1.5 & 1.7 \\
\hline Microtendipes pedellus-type & Mict ped & 0.0 & 0.8 & 2.9 & 0.0 & 1.4 & 5.6 & 2.0 & 0.7 & 2.6 \\
\hline Omisus caledonicus & Omis cal & 0.0 & 0.0 & 0.0 & 0.0 & 0.0 & 0.0 & 0.0 & 0.0 & 0.9 \\
\hline Pagastiella orophila & Paga oro & 0.0 & 1.5 & 0.0 & 0.0 & 0.7 & 1.6 & 0.0 & 0.0 & 0.0 \\
\hline Phaenopsectra flavipes-type & Phae fla & 1.9 & 0.8 & 0.0 & 1.6 & 0.0 & 1.6 & 0.0 & 0.0 & 0.0 \\
\hline Parachironomus varus-type & Parc var & 0.0 & 0.0 & 0.0 & 0.0 & 0.0 & 0.0 & 0.0 & 0.0 & 3.4 \\
\hline Paratendipes albimanus-type & Patd alb & 5.8 & 0.0 & 0.0 & 0.0 & 0.0 & 0.0 & 0.0 & 0.0 & 0.0 \\
\hline Polypedilum sordens-type & Poly sor & 0.0 & 0.0 & 0.0 & 0.0 & 0.0 & 0.8 & 0.0 & 0.7 & 3.4 \\
\hline Polypedilum nubeculosum-type & Poly nuc & 0.0 & 0.8 & 2.9 & 0.8 & 1.4 & 0.0 & 2.0 & 1.5 & 0.9 \\
\hline Pseudochironomus prasinatus-type & Pseu pra & 0.0 & 0.0 & 2.9 & 1.6 & 1.4 & 2.4 & 0.0 & 0.0 & 0.0 \\
\hline Cladotanytarsus mancus-type & Clat man & 0.0 & 0.8 & 2.9 & 0.0 & 1.4 & 11.3 & 0.0 & 2.2 & 0.0 \\
\hline Corynocera ambigua & Cory amb & 0.0 & 0.0 & 0.0 & 0.0 & 0.0 & 4.0 & 0.0 & 2.2 & 0.0 \\
\hline Rheotanytarsus & Rhetind & 0.0 & 0.8 & 0.0 & 0.0 & 0.0 & 0.0 & 2.0 & 2.2 & 4.3 \\
\hline Stempellinella & Stepind & 0.0 & 0.0 & 0.0 & 0.0 & 0.0 & 0.0 & 0.0 & 0.7 & 0.0 \\
\hline Tanytarsus undif. & Tanyind & 0.0 & 3.8 & 3.7 & 4.7 & 6.4 & 4.8 & 2.0 & 8.0 & 6.9 \\
\hline Tanytarsus lactescens-typ & Tany lac & 0.0 & 4.6 & 3.7 & 0.0 & 0.0 & 0.8 & 0.0 & 0.0 & 0.0 \\
\hline Tanytarsus mendax-type & Tany men & 0.0 & 10.0 & 14.0 & 7.8 & 4.3 & 4.8 & 0.0 & 6.6 & 0.0 \\
\hline Tanytarsus pallidicornis-type & Tany pal & 0.0 & 9.2 & 2.2 & 12.4 & 8.5 & 1.6 & 0.0 & 5.1 & 1.7 \\
\hline Tanytarsus glabrescens-type & Tany gla & 0.0 & 1.5 & 1.5 & 0.8 & 0.0 & 0.0 & 0.0 & 0.0 & 0.0 \\
\hline $\begin{array}{l}\text { Tanytarsus chinyensis-type } \\
\text { CHAOBORIDAE }\end{array}$ & Tany chi & 0.0 & 0.8 & 0.0 & 0.0 & 0.7 & 7.3 & 0.0 & 1.5 & 0.0 \\
\hline $\begin{array}{l}\text { Chaoborus flavicans } \\
\text { CERATOPOGONIDAE }\end{array}$ & Chao fla & 10.2 & 0.0 & 0.0 & 0.0 & 0.0 & 0.0 & 48.7 & 1.4 & 0.8 \\
\hline Bezzia-type & Bezzind & 0.8 & 0.8 & 0.7 & 0.0 & 2.0 & 3.7 & 1.3 & 0.0 & 1.5 \\
\hline EPHEMEROPTERA & Epheind & 0.8 & 0.0 & 0.0 & 0.0 & 0.0 & 3.7 & 2.2 & 2.1 & 2.3 \\
\hline ORIBATIDA & Oribind & 0.0 & 0.0 & 0.7 & 0.0 & 4.6 & 0.0 & 3.5 & 0.7 & 7.6 \\
\hline TRICOPTERA & Tricind & 0.0 & 0.0 & 0.0 & 0.0 & 0.0 & 0.0 & 0.0 & 1.4 & 0.0 \\
\hline Total number of taxa & & 39 & 41 & 48 & 37 & 41 & 51 & 43 & 54 & 43 \\
\hline
\end{tabular}




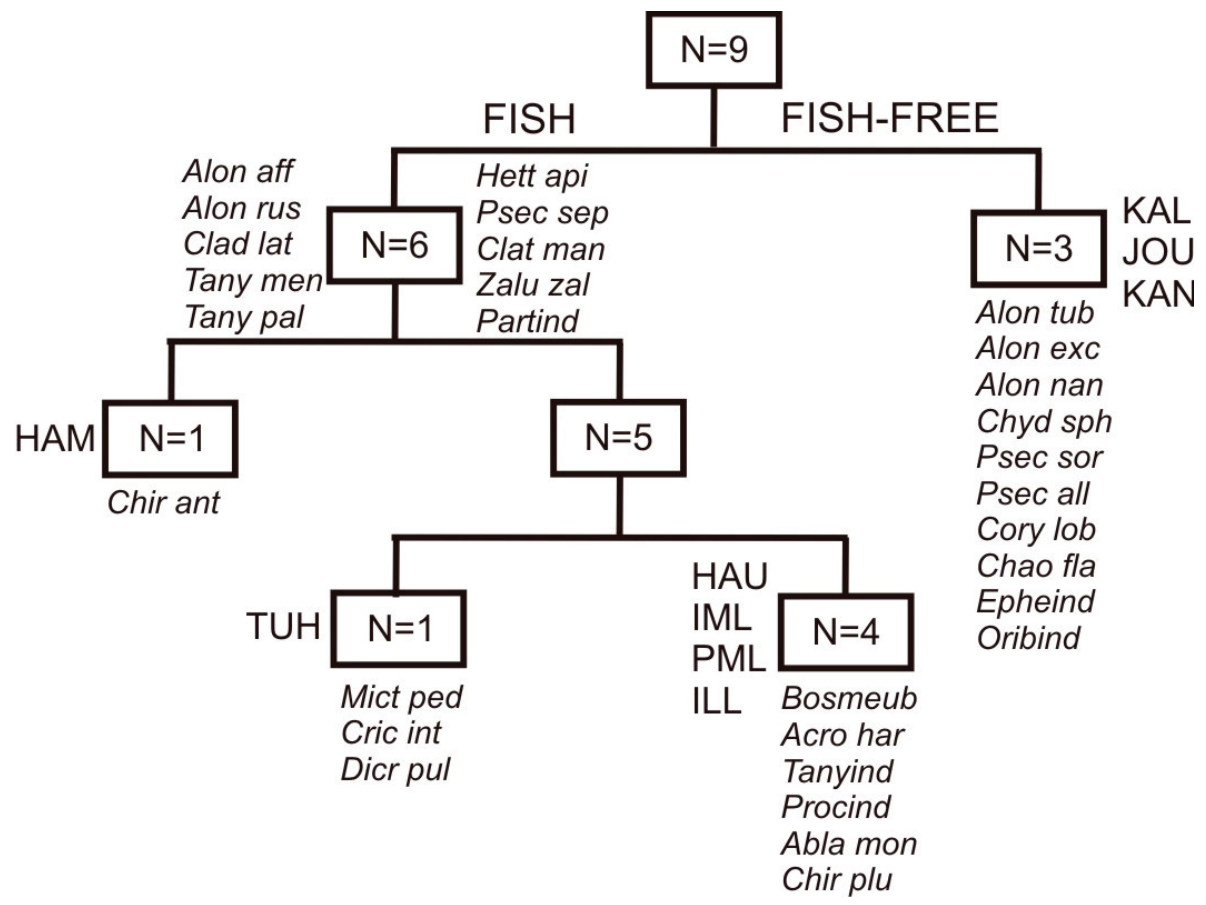

\section{Figure 2}

TWINSPAN classification of the study lakes according to their invertebrate assemblages and indicator species for each lake group. The abbreviations of the taxa are shown in Table II.

\section{Figure 2}

Classification TWINSPAN des lacs étudiés selon leurs assemblages d'invertébrés et espèces indicatrices pour chaque groupe de lacs.

\section{Table III}

RDA statistics for the tested environmental variables and invertebrate assemblages.

Tableau III

Statistiques RDA pour les variables environnementales testées et les assemblages d'invertébrés

\begin{tabular}{|l|c|c|c|c|}
\hline & $\lambda_{1}: \lambda_{2}$ & $P$-value & Species-environment correlation & Cumulative variance \% \\
\hline Fish & 1.832 & 0.001 & 0.969 & 37.0 \\
pH & 0.678 & 0.061 & 0.917 & 23.6 \\
Conductivity & 0.660 & 0.112 & 0.893 & 22.5 \\
DO & 1.266 & 0.001 & 0.887 & 29.5 \\
Color & 1.237 & 0.002 & 0.901 & 29.2 \\
TP & 0.688 & 0.050 & 0.924 & 24.0 \\
\hline
\end{tabular}

in the RDAs were fish (presence or absence), $\mathrm{pH}$, conductivity, DO, color and TP. The analysis showed that fish, DO, color and TP related significantly $(P \leq 0.05)$ with the invertebrate assemblages (Table III). The assemblages were most strongly correlated with fish status $\left(\lambda_{1}: \lambda_{2}=1.832, P=0.001\right)$. In the RDA ordination for samples, taxa related to fish presence, e.g. Cladopelma lateralis-type, Tanytarsus pallidicornis-type, and Chironomus anthracinustype had negative values for RDA axis 1 and low values for axis 2 (Figure 3). Of the environmental variables DO was related to fish presence, but taxa associated with high DO had negative values for both RDA axis (e.g. Alona affinis, Alonopsis elongata, Psectrocladius sordidellus-type, and Heterotrissocladius apicalis-type). At the opposite side of the ordination, taxa related to high water color and absence of fish, such as Corynoneura lobata-type, Limnophyes, Nanocladius rectinervis-type, Chaoborus flavicans, Alonella excisa, Daphnia, Simocephalus, and Holopedium gibberum had high values for RDA axis 1 and slightly 


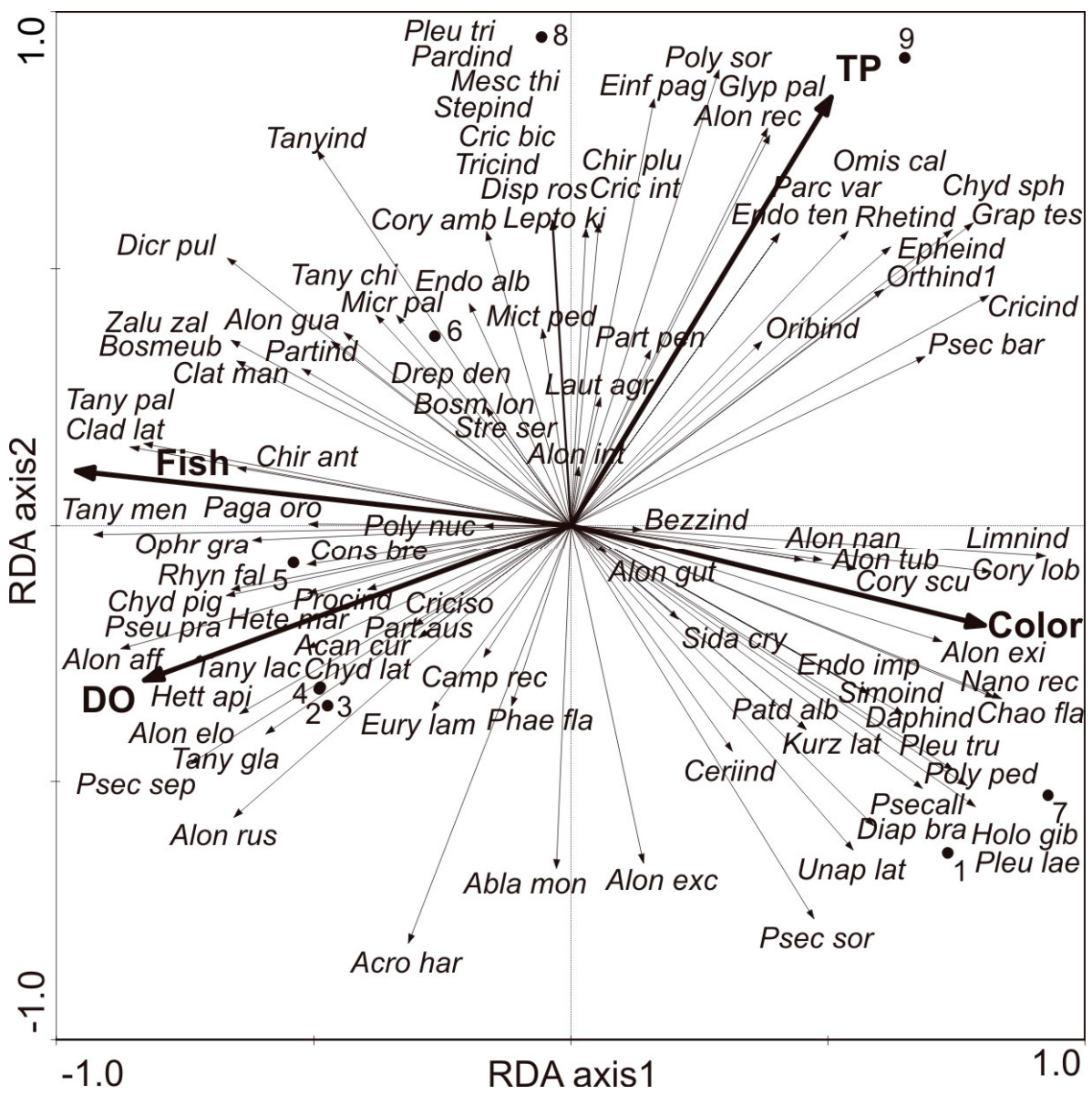

\section{Figure 3}

RDA ordination for samples (lakes 1-9 according to Table I), environmental variables, and invertebrate taxa. The abbreviations of the taxa are shown in Table II.

\section{Figure 3}

Ordination RDA des échantillons (lacs 1-9 selon le tableau I), variables environnementales et taxons d'invertébrés. Les abréviations des taxons sont celles du tableau II.

negative values for axis 2. Relationship between taxa (e.g. Glyptotendipes pallens-type and Alona rectangular) and TP were shown as high values for both RDA axes.

\section{DISCUSSION}

The TWINSPAN classification of the nine study lakes according to their invertebrate assemblages showed that the three lakes with no permanent fish stocks were grouped together (Figure 2), suggesting that the faunal assemblages in fish-free lakes differ from those with fish. The indicator species for fish-free lakes included Oribatida, Ephemeroptera, and Chaoborus flavicans. This is not surprising, since Oribatida (oribatid mites) and Ephemeroptera (may flies) are large-sized and therefore easily caught by fish for consumption. Chaoborus flavicans (the phantom midge) is known to co-occur with fish only in deep and stratified lakes, which provide refugia in the hypolimnion, in clay-turbid lakes that prevent visual predation by fish (LiljendahlNurminen, 2006), and in humic brown-watered lakes that have reduced fish predation potential due to their light-, oxygen-, and temperature profiles (Paasivirta, 1982). In fish-free lakes invertebrates, such as Chaoborus larvae may become the top predators (Nyberg, 1998) and in small and shallow lakes the presence or absence of $C$. flavicans is suggested to be regulated 
by fish predation (Luoto and Nevalainen, 2009). Therefore, Chaoborus flavicans seems to be a good indicator species of fish-free environments in the current data set of small shallow lakes (Figure 2), coherently with the results from the above mentioned previous studies.

According to the TWINSPAN analysis, small species of the family Chydoridae of the Cladocera; Chydorus sphaericus s.l., Alonella nana, Alonella excisa, and Alona guttata var. tuberculata were indicators of the fish-free lakes (Figure 2), although they occurred in all the lakes (Table II). This result is contradictory to many other results, since usually large and visible cladoceran species, such as Daphnia spp., succeed in fish-free waters (Kerfoot, 1974; Jeppesen et al., 2001b) in the expense of small cladocerans (Arnott and Vanni, 1993). Therefore, it is possible that the small chydorid species are not actually indicators of the absence of fish, but such limnological conditions that inhibit success of fish. For example, two of the three fish-free lakes are humic lakes (Kalatoin and Jousjärvi), which contain only a narrow photic and oxygenated epilimnion and therefore suffer from oxygen depletion during winters. Lake Kangaslampi, on the other hand, is extremely eutrophic and disturbed basin and therefore summer algal blooms and winter oxygen depletion restrain permanent inhabitation of fish. In fact, the small chydorids may actually be indicators of fish-free lakes when Chaoborus is the top predator. Fitting well with this interpretation, Irfanullah and Moss (2005) showed that a relatively small cladoceran species, $C$. sphaericus succeeded and remained unaffected by Chaoborus predation due to its high reproductive rate compensating predation loses.

In the TWINSPAN classification the four oligotrophic lakes (Hauklampi, Iso Majaslampi, Pieni Majaslampi, Iso Lehmälampi) currently inhabited by fish form a separate cluster (Figure 2, Table I). All these lakes experienced severe acidification and related fish kills during the 1980s. This separate cluster with species such as cladoceran Bosmina (Eubosmina) and chironomid Procladius may indicate limnological and ecological conditions where recent fish introductions have taken place causing distict invertebrate assemblages to succeed or where slow biological recovery following the acidification is under process (Holt and Yun, 2003; Nyberg et al., 2010).

The multivariate RDA ordination for environmental variables and invertebrate taxa in the case of $C$. flavicans (Figure 3 ) is in accordance with the TWINSPAN classification (Figure 2), showing that $C$. flavicans is successful in fish-free environments. The ordination also revealed a relationship between many planktonic cladoceran species and fish absence. Large and visible planktonic taxa Daphnia spp., Ceriodaphnia spp., Simocephalus spp., Holopedium gibberum and Diaphanosoma brachyurum occurred mostly in fish-free lakes, since they easily fall prey to fish and are an important part of the fish diet (cf. Brooks and Dodson, 1965; Zaret, 1972). However, the remains of planktonic cladocerans were rare, as e.g. Daphnia and Simocephalus were found only in one lake (Table II). Many of the study lakes are very acidic and have an acidification history that may have affected the infrequency of Daphnia in the dataset. Recently, Jeziorski et al. (2008) showed that acidic deposition and lack of calcium in Canadian boreal shield lakes, comparable to boreal lakes in Finland, nearly extirpated some Daphnia species. Therefore, the cause behind scarcity of Daphnia may be the chemical composition of the water. In addition, the preservation of Daphnia remains may also vary among lakes, possibly connected to water chemistry (Sarmaja-Korjonen, 2007). Thus, according to the present results from the nine lake data set, no significant conclusions can be made about whether these taxa are truly related to fish-free environments in shallow basins.

The RDA statistics showed a high and significant correlation between fish and invertebrate assemblages (Table III), indicating good potential to infer past changes in fish status when the data set is expanded in the future. In the future, more fish-free lakes should be added into the data set and, in overall, the future calibration set should have evenly distributed environmental gradients, including similar amount of lakes with and without fish present. When the data set is expanded with limnologically variable sites, it is more probable that the signal of the influence of fish on invertebrate communities can be separated from those of other limnological conditions. Since the presence and absence of fish is indicated by binary codes, not as actual size of fish stocks, it cannot represent the actual abundance of fish, but rather the trends in fish status when reconstructed from downcore fossil invertebrate assemblages. 
In this respect, the fish index to be developed can be regarded as a semi-quantitative method to detect changes in fish status of lakes and should be enlarged to cover at least 30 lakes for reliable validations and regional applicability. Although the determination of fish presence in lakes is very difficult and time-consuming, partly due to the uncommonness of fish-free lakes, it is still utmost important to carefully assess the lake-specific fish status.

As suggested by Sweetman and Smol (2006), multi-proxy investigations of fossil invertebrate remains may allow paleolimnological interpretations of past changes in fish status in lakes. Our results of local invertebrate assemblages in surface sediments of the nine lakes imply that the use of various ecologically different faunal groups and numerous taxa together may allow tracking of presence and absence of fish and therefore support the proposal of Sweetman and Smol (2006). To conclude, the present tentative implications may further enhance the knowledge of internal and long-term food-web processes in lakes, although plenty of work in enlarging the data set will be required before applicable reconstructions at different regions can be performed.

\section{REFERENCES}

Arnott S.E. and Vanni M.J., 1993. Zooplankton assemblages in fishless bog lakes - influence of biotic and abiotic factors. Ecology, 74, 2361-2380.

Brooks J.L. and Dodson S.I., 1965. Predation, body size, and composition of plankton. Science, 150, 28-35.

Brooks S.J., Langdon P.G. and Heiri O., 2007. The identification and use of Palearctic Chironomidae larvae in palaeoecology, QRA Technical Guide, 10, Quaternary Research Association, London.

Brönmark C. and Hansson L.-A., 2002. Environmental issues in lakes and ponds: current state and perspectives. Environ. Conserv., 29, 290-306.

Davidson T.A., Sayer C.D., Perrow M.R., Bramm M. and Jeppesen E., 2007. Are the controls of species composition similar for contemporary and sub-fossil cladoceran assemblages? A study of 39 shallow lakes of contrasting trophic status. J. Paleolimnol., 38, 117-134.

Hill M.O. and Šmilauer P., 2005. TWINSPAN for Windows, Version 2.3, Centre for Ecology and Hydrology, University of South Bohemia, Huntington \& České Budejovicě.

Holt C. and Yun N.D., 2003. Recovery of crustacean zooplankton communities from acidification in Killarney Park, Ontario, 1971-2000: pH 6 as a recovery goal. Ambio, 32, 203-207.

Horppila J., Peltonen H., Malinen T., Luokkanen E. and Kairesalo T., 1998. Top-down or bottom-up effects by fish: Issues of concern in biomanipulation of lakes. Restoration Ecol., 6, 20-28.

Irfanullah H. and Moss B., 2005. Effects of $\mathrm{pH}$ and predation by Chaoborus larvae on the plankton of a shallow and acidic forest lake. Freshw. Biol., 50, 1913-1926.

Jeppesen E., Madsen E.A. and Jensen J.P., 1996. Reconstructing the past density of planktivorous fish and trophic structure from sedimentary zooplankton fossils: a surface sediment calibration data set from shallow lakes. Freshw. Biol., 36, 115-127.

Jeppesen E., Leavitt P., De Meester L. and Jensen J.P., 2001a. Functional ecology and palaeolimnology: using cladoceran remains to reconstruct anthropogenic impact. Trends Ecol. Evol., 16, 191-198.

Jeppesen E., Christofferssen C., Landkildehus F. and Lauridsen T., 2001b. Fish and crustacean in northeast Greenland lakes with special emphasis on interactions between Arctic charr (Salvelinus alpinus), Lepidurus arcticus and benthic chydorids. Hydrobiologia, 442, 329-337.

Jeppesen E., Jensen J.P., Amsinck S., Landkildehus F., Lauridsen T. and Mitchell S.F., 2002. Reconstructing the historical changes in Daphnia mean size and planktivorous fish abundance in lakes from the size of Daphnia ephippia in the sediment. J. Paleolimnol., 27, 133-143.

Jeppesen E., Jensen J.P., Lauridsen T., Amsinck S.L., Christofferssen K., Sønderrgaard and Mitchell S.F., 2003. Sub-fossils of cladocerans in the surface sediment of 135 lakes as proxies for community structure of zooplankton, fish abundance and lake temperature. Hydrobiologia, 491, 321-330.

Jeziorski A., Yan N.D., Paterson A.M., DeSellas A.M., Turner M.A., Jeffries D.S., Keller B., Weeber R.C., McNicol D.K., Palmer M.E., Mclver K., Arsenau K., Ginn B.K., Cumming B.F. and Smol J.P., 2008. The widespread threat of calcium decline in fresh waters. Science, 322, 1374-1377.

Kauppi P., Anttila P. and Kenttämies K. (eds.), 1990. Acidification in Finland, Springer-Verlag, Berlin. 
Kerfoot W.C., 1974. Net accumulation rates and the history of cladoceran communities. Ecology, 55, 51-61.

Kerfoot W.C., 1981. Long-term replacement cycles in cladoceran communities: A history of predation. Ecology, 62, 216-233.

Kitchell J.A. and Kitchell J.F., 1980. Size-selective predation, light transmission, and oxygenstratification: Evidence from the recent sediments of manipulated lakes. Limnol. Oceanogr., 25, 389-402.

Kornijóv R., Vakkilainen K., Horppila J., Luokkanen E. and Kairesalo T., 2005. Impacts of a submerged plant (Elodea canadensis) on interactions between roach (Rutilus rutilus) and its invertebrate prey communities in a lake littoral zone. Freshw. Biol., 50, 262-276.

Liljendahl-Nurminen A., 2006. Invertebrate predation and trophic cascades in a pelagic food web - the multiple roles of Chaoborus flavicans (Meigen) in a clay-turbid lake, Ph.D. Thesis, Department of Biological and Environmental Sciences, University of Helsinki.

Lotter A.F., Birks H.J.B., Hofmann W. and Marchetto A., 1997. Modern diatom, cladocera, chironomid, and chrysophyte cyst assemblages as quantitative indicators for the reconstruction of past environmental conditions in the Alps. I. Climate. J. Paleolimnol., 18, 395-420.

Lotter A.F., Birks H.J.B., Hofmann W. and Marchetto A., 1998. Modern diatom, cladocera, chironomid, and chrysophyte cyst assemblages as quantitative indicators for the reconstruction of past environmental conditions in the Alps. II. Nutrients. J. Paleolimnol., 19, 443-463.

Luoto T.P., 2009. An assessment of lentic ceratopogonids, ephemeropterans, trichopterans and oribatid mites as indicators of past environmental change in Finland. Ann. Zool. Fennici, 46, 259-270.

Luoto T.P. and Nevalainen L., 2009. Larval chaoborid mandibles in surface sediments of small shallow lakes in Finland: implications for paleolimnology. Hydrobiologia, 631, 185-195.

Luoto T.P., Nevalainen L. and Sarmaja-Korjonen K., 2008. Multiproxy evidence for the 'Little Ice Age' from Lake Hamträsk, southern Finland. J. Paleolimnol., 40, 1097-1113.

Manca M., Torretta B., Comoli P., Amsinck S.L. and Jeppesen E., 2007. Major changes in trophic dynamics in large, deep sub-alpine Lake Maggiatore from 1940s to 2002: a high resolution comparative palaeo-neolimnological study. Freshw. Biol., 52, 2256-2269.

Nyberg P., 1998. Biotic effects in planktonic crustacean communities in acidified Swedish forest lakes after liming. Water Air Soil Pollut., 101, 257-288.

Nyberg K., Vuorenmaa J., Tammi J., Nummi P., Väänänen V.-M., Mannio J. and Rask M., 2010. Reestablishment of perch in three lakes recovering from acidification: rapid growth associated with abundant food resources. Bor. Env. Res., 15.

Nykänen M., Liukkonen M. and Kairesalo T., 2006. Changes of predations pressure by fish in Lake Vesijärvi by sedimentary cladoceran remains. Verh. Internat. Verein. Limnol., 29, 1321-1326.

Paasivirta L., 1982. Saarijärven Pyhä-Häkin makroskooppinen pohjaeläimistö. Bulletin of the University of Jyväskylä, 29, 31-39 (in Finnish).

Patterson W.P. and Smith G.R., 2001. Fish. In: Smol J.P., Birks H.J.B. and Last W.M. (eds.), Tracking Environmental Change Using Lake Sediments: Zoological Indicators - Developments in Paleoenvironmental Research, 4, Kluwer Academic Publishers, Dordrecht, 173-187.

Salo J., Walls M., Rajasilta M., Sarvala J., Räsänen M. and Salonen V.-P., 1989. Fish predation and reduction in body size in a cladoceran population: paleoecological evidence. Freshw. Biol., 21, 217-221.

Salonen V.-P., Tuovinen N. and Valopola S., 2006. History of mine drainage impact on Lake Orijärvi algal communities, SW Finland. J. Paleolimnol., 35, 289-303.

Sarmaja-Korjonen K., 2002. Multi-proxy data from Kaksoislammpi Lake in Finland: dramatic changes in the late Holocene cladoceran assemblages. J. Paleolimnol., 28, 287-296.

Sarmaja-Korjonen K., 2007. Subfossil shell margins and tail spines of Daphnia in Finnish lake sediments - is Daphnia underrepresented in Cladocera analysis? Studia Quaternaria, 24, 61-64.

Smol J.P. and Douglas M.S.V., 2007. From controversy to consenses: making the case for recent climate change in the Arctic using lake sediments. Front. Ecol. Environ., 5, 466-474.

Smol J.P., Wolfe A.P., Birks H.J.B., Douglas M.S.V., Jones V.J., Korhola A., Pienitz R., Rühlan K., Sorvari S., Antonisdes D., Brooks S.J., Fallu M.-A., Hughes M., Bronwyn E.K., Laing T.E., Michelutti N., Nazarova N., Nyman M., Paterson A.M., Perren P., Quinlan R., Rautio M., Saulnier-Talbot E., Siitonen S., Solovieva N. and Weckström J., 2005. Climate-driven regime shifts in the biological communities of Arctic lakes. Proc. Natl. Acad. Sci., 102, 4397-4402. 
Sweetman J.N. and Smol J.P., 2006. Reconstructing fish populations using Chaoborus (Diptera: Chaoboridae) remains - a review. Quat. Sci. Rev., 25, 2013-2023.

Szeroczyńska K. and Sarmaja-Korjonen K., 2007. Atlas of subfossil Cladocera from Central and Northern Europe, Friends of the Lower Vistula Society, Świecie.

ter Braak C.J.F., 2003. Program CANOCO, Version 4.52. Biometris - quantitative methods in the life and earth sciences, Plant Research International, Wageningen University and Research Centre, The Netherlands.

Uutala A.J., 1990. Chaoborus (Diptera: Chaoboridae) mandibles - paleolimnological indicators of the historical status of fish populations in acid-sensitive lakes. J. Paleolimnol., 4, 139-151.

Vanni M.J., Layne C.D. and Arnott S.E., 1997. "Top-down" trophic interactions in lakes: effects of fish on nutrient dynamics. Ecology, 78, 1-20.

Vašek M., Kubečka J., Matěna J. and Seda J., 2006. Distribution and diet of 0+ fish within a canyonshaped European reservoir in late summer. Internat. Rev. Hydrobiol., 91, 178-194.

Verta M., Mannio J., livonen P., Hirvi J.-P., Järvinen O. and Piepponen S., 1990. Trace metals in Finnish headwater lakes - effects of acidification and airborne load. In: Kauppi P., Anttila P. and Kenttämies K. (eds.), Acidification in Finland, Springer-Verlag, Berlin, 883-908.

Zaret T.M., 1972. Predation, invisible prey, and the nature of polymorphism in the Cladocera (class Crustacea). Limnol. Oceanogr., 17, 171-184.

Zaret T.M. and Kerfoot W.C., 1975. Fish predation on Bosmina longirostris; body-size versus visibility selection. Ecology, 56, 232-237. 